\title{
IMPLEMENTASI SIKAP HORMAT PADA SEKOLAH BERBASIS HUMANISTIK, SD SANGGAR ANAK ALAM
}

\author{
Andreas Erwin Prasetya \\ Pendidikan Guru Sekolah Dasar, Universitas Sanata Dharma \\ Jl. Mrican Baru, Kabupaten Sleman \\ Email: andreaserwin@usd.ac.id
}

\begin{abstract}
Abstrak
Penelitian ini berangkat dari keprihatinan terhadap rendahnya penghormatan antara guru dengan siswa atau sebaliknya. Berdasarkan keprihatinan tersebut, penelitian ini bertujuan untuk untuk mengungkap model penghormatan seperti yang diterapkan di satu sekolah yang menjunjung nilai humanistik yaitu SD Sanggar Anak Alam (SD Salam). Metode penelitian ini adalah studi kasus. Pengumpulan data dilakukan dengan observasi, wawancara, serta studi dokumentasi untuk memperoleh data mengenai implementasi sikap hormat di dalam pembelajaran maupun di luar pembelajaran. Kemudian data dianalisis menggunakan tahapan penyajian data, reduksi data, dan penarikan kesimpulan. Dari proses tersebut peneliti menyimpulkan bahwa terdapat dua bentuk penghormatan di SD Salam, yaitu (1) penghormatan terwujud melalui dialog yang setara antara siswa dengan fasilitator atau sebaliknya, (2) penghormatan terwujud melalui kegiatan bersama diantaranya mengantri, mendengarkan teman yang berbicara, menyelesaikan konflik antar teman, dan siswa yang saling membaur.
\end{abstract}

\author{
Kata Kunci: \\ Sikap hormat, humanistik
}

\begin{abstract}
This study started from concern over the lack of respect between teachers and students, or vice versa. Based on these concerns, researchers sought to uncover the model of respect as applied in a school that based on humanistic values, namely SD Sanggar Anak Alam (SD Salam). Researchers conducted observations, interviews, and study documentation to obtain data on the implementation of a respectful attitude inside of learning and outside of learning. Then the data are analyzed using the stages of data display, data reduction, and conclusions. From this process, the researchers concluded that there were two forms of respect in SD Salam, There were (1) respect was realized through equal dialogue between students and facilitators or vice versa, (2) respect was realized through joint activities including queuing, listening to friends, resolving conflicts between friends, and students who mingle each other.
\end{abstract}

Keywords:

Respect, humanism

\section{A. PENDAHULUAN}

Dewasa ini, di media sosial dan televisi banyak beredar video disertai dengan cerita siswa yang memukul, mencemooh, mengejek, bahkan mengancam guru dengan menggunakan senjata tajam. Hal tersebut siswa lakukan karena berbagai macam alasan. Salah satu alasan adalah siswa yang HP-nya disita oleh guru karena peraturan sekolah yang melarang siswa menggunakan HP saat pembelajaran berlangsung. Tidak hanya dari siswa, kekerasan dalam pendidikan juga berasal dari guru. Atas nama disiplin dan ketertiban, guru tidak segan untuk memukul atau menyakiti siswanya. Atas tindakan tersebut, beberapa guru harus menjalani proses hukum untuk mempertanggungjawabkan tindakannya.

Isu tersebut dikonfirmasi oleh data dari Komisi Perlindungan Anak Indonesia (KPAI) tahun 2017 bahwa kekerasan pada anak yang terjadi di dunia pendidikan menempati peringkat ke-3 terbanyak dengan 2.345 kasus. Tentu kejadian riil di lapangan lebih dari angka tersebut karena masih banyak yang belum terlaporkan. Hingga saat ini sebagian guru masih beranggapan bahwa kekerasan masih dianggap efektif untuk mendisiplinkan siswa. Data dari UNICEF menunjukan bahwa terdapat sekitar $80 \%$ kekerasan yang terjadi di sekolah dilakukan oleh guru kepada siswa (UNICEF, 2006). Fakta mengenai kekerasan baik berupa fisik maupun mental tersebut tentu bertolak belakang prinsipprinsip pendidikan yang humanis.

Pendidikan yang humanis bertujuan untuk memekarkan dan memaksimalkan potensi siswa. Pemaksimalan potensi tersebut dilakukan dengan menjunjung tinggi keluhuran dan martabat manusia (Schillebeeckx, 1993:1-4). Pada umumnya, titik tolak yang dijadikan acuan oleh para pemikir pendidikan humanistik adalah potensi manusia yang harus digali sedalam- 
dalamnya dan seluas-luasnya tanpa dibatasi oleh berbagai dogma. Seperti yang dikatakan oleh Aloni:

"Humanistic education is characterized by general and multi-faceted cultivation of the personality of those being educated, in a climate of intellectual freedom and respect for human dignity, towards the best and highest life of which they are capable in there fundamental domains of life: as individual who harmoniously and authentically realize their potential, as involved and responsible citizens in a democracy, and as human beings who enrich and perfect themselves through active engagement with the collective achievement of human culture." (Aloni, 2007: 77)

Pengertian di atas memberikan gambaran yang cukup komprehensif bahwa pendidikan humanistik merupakan usaha untuk membentuk manusia yang memiliki aspek dimensional dengan kondisi belajar penuh dengan kebebasan dan penghargaan atas martabat manusia. Selanjutnya dalam lingkup demokrasi Aloni juga menguraikan bahwa manusia harus menyadari sepenuhnya potensi diri. Apabila diperhatikan lebih detail pengertian tersebut juga menyebutkan respek atau penghormatan sebagai syarat lingkungan dengan pendidikan berbasis humanistik. Penghormatan dalam tataran praktis tersebut yang akan menjadi fokus tulisan ini.

Pembahasan mengenai penghormatan sebenarnya telah dimulai oleh para filsuf sejak abad ke-18. Immanuel Kant menekankan bahwa seseorang harus menghormati diri sendiri dan orang lain untuk mewujudkan hidup yang bermartabat. Esensi penghormatan adalah menghargai, perhatian, memberikan nilai, dan menyukai (Eliasa, 2011: 5). Selain itu penghormatan juga untuk menunjukan bagaimana sikap seseorang secara serius dan khidmat pada orang lain dan diri sendiri. Menghormati orang lain berarti memberikan satu pertanda atau kondisi dimana orang lain yang kita hormati merasa aman, bahagia, dan merasa penting karena perannya. Rasa hormat dapat ditunjukan dengan sikap sopan dan juga membalas dengan kebaik hatian, baik berupa sikap maupun pemberian. Sikap hormat juga berarti toleran, terbuka, dan menerima perbedaan.

Sikap hormat tidak berarti dapat dilakukan secara berlebihan. Dengan begitu menghormati bukan berarti sikap patuh dan menjilat orang lain (Mu'in, 2011:212). Dalam hubungan yang menempatkan seseorang sebagai bawahan-atasan, penguasa-rakyat, bos-anak buah, dst. belum tentu menjamin rasa hormat yang dibangun oleh masing-masing pihak syarat akan makna. Dalam hubungan yang dibalut dengan kekuasaan, rasa hormat cenderung dimaknai secara dangkal. Penghormatan lebih dilakukan karena rasa takut, hubungan formal, terdesak, tertekan, atau hanya untuk memenuhi aturan. Dengan demikian, rasa hormat harus dilakukan atas dasar bahwa seluruh individu (termasuk diri kita) pada dasarnya adalah penting dan tiap manusia memiliki tujuan moral, sehingga penghargaan martabat dan eksistensi manusia merupakan dasar dari rasa hormat.

Aspek lain dari penghormatan adalah nonpossessive warmth. Hal tersebut berarti bahwa seseorang menghormati karena melihat diri orang lain dengan dengan penuh kepercayaan dan cinta yang tulus tanpa syarat. Apabila aspek ini berjalan dalam sebuah hubungan maka sikapsikap seperti terbuka, jujur, dan genuine akan muncul (Patterson, 1985: 50-63). Dengan kata lain agar penghormatan dapat muncul dalam sebuah hubungan harus ada sebuah penerimaan tanpa melihat kondisi orang lain.

Dalam konteks pembelajaran di kelas, Guru dan siswa hendaknya membangun sikap hormat satu dengan yang lain. Walaupun kedua belah pihak memiliki kewajiban untuk saling menghormati, namun peran gurulah yang lebih sentral untuk membangun kultur penghormatan yang sesuai dengan martabat manusia. Upaya yang dapat dilakukan guru untuk membangun penghormatan yang bermartabat diantaranya (1) menjaga komunikasi yang efektif, (2) berkomunikasi secara kontinu dan memiliki harapan tinggi pada siswa, dan (3) mengatasi masalah-masalah non akademis.

Dari pembahasan yang telah diuraikan tersebut, menjadi penting untuk mencari bentuk penghormatan seperti apa yang dapat dijadikan model kajian. Maka, tujuan dari penulisan artikel ini adalah mendeskripsikan bagaimana sekolah yang berlandaskan pada prinsip-prinsip humanistik memaknai dan mengimplementasikan penghormatan antara fasilitator dengan siswa, siswa dengan fasilitator, dan fasilitator dengan fasilitator. Diharapkan tulisan ini juga mampu memberikan referensi dan inspirasi bagi mengimplementasikan sikap hormat.

Penelitian ini bertujuan untuk menguraikan bagaimana bentuk sikap hormat yang terwujud dalam keseharian di SD Sanggar Anak Alam 
(Salam). Untuk itu, peneliti menggunakan metode penelitian kualitatif studi kasus. Metode penelitian kualitatif memungkinkan penelitian dijalankan dengan eksploratif berbekal pertanyaan terbuka (Creswell, 2012: 258-259). Menurut Frankel \& Wallen (2006: 431-432) penelitian kualitatif memiliki karakter (1) natural, (2) bergantung pada kemampuan komunikasi, (3) bersifat terbuka, (4) instrumen penelitian berkembang sesuai situasi, (5) catatan lapangan merupakan sumber data, (6) pengolahan data menyeluruh meliputi reduksi dan abstraksi, (7) memiliki validitas eksternal rendah.

Berdasar karakteristik tersebut peneliti menggunakan wawancara mendalam, dokumentasi dan observasi sebagai teknik pengumpulan data. Sementara instrumennya adalah peneliti sendiri (Bogdan \& Biklen, 2003). Peneliti juga menggunakan piranti untuk merekam hasil wawancara (recorder) dan catatan lapangan untuk menuliskan hasil observasi partisipatif. Peneliti sebagai instrumen utama penelitian memiliki beberapa implikasi yang mendukung pelaksanaan penelitian. Implikasi tersebut diantaranya (1) peneliti memiliki kesempatan langsung untuk berpartisipasi dengan subjek penelitian, (2) peneliti membutuhkan waktu untuk adaptasi agar mampu menyelami dinamika keseharian informan, (3) peneliti diharapkan mampu membaca fakta dan fenomena konkret yang berkaitan dengan tujuan penelitian, (4) peneliti dapat lebih selektif untuk mengumpulkan data agar relevan dengan tujuan penelitian.

Penelitian ini dilakukan di SD Sanggar Anak Alam (SD Salam), Yogyakarta. Lokasi penelitian ini dipilih oleh peneliti dengan alasan pertama pendiri SD Salam adalah Ibu Sri Wahyaningsih yang merupakan murid dari Y.B. Mangunwijaya aktivis pendidikan humanistik yang juga berkarya dalam bidang kemanusiaan, sosial, hingga arsitektur. Dari sisi ini, peneliti berasumsi bahwa sisi kemanusiaan ditumbuhkan dengan kuat di dalam sekolah ini. Kedua, latar belakang siswa yang bersekolah di SD Salam adalah mayoritas berasal dari keluarga menengah ke bawah namun memiliki sikap aktif, eksploratif dan kritis yang baik (Raharjo, 2015: 3950). Ketiga, terjalin hubungan yang akrab dan dekat antara siswa dengan fasilitator namun tidak mengurangi rasa hormat siswa kepada fasilitator.

Sementara itu, data digali dari beberapa sumber diantaranya (1) guru/Fasilitator, (2) kepala sekolah, (3) kegiatan belajar mengajar, (4) dokumen terkait. Data kemudian dianalisis dengan metode dari Miles dan Huberman (1992: 20) dengan tahapan (1) pengumpulan data, (2) penyajian data, (3) reduksi data, (4) penarikan kesimpulan. Tahapan diawali dari pengumpulan data untuk mendapatkan data mentah. Selanjutnya data mentah tersebut diorganisasi agar mudah untuk disajikan. Setelah data tersaji, mulailah data direduksi dengan melihat kecenderungan data dan dikelompokkan berdasarkan tema-tema tertentu. Berdasarkan tema-tema tersebut, peneliti menyusun kesimpulan sebagai jawaban dari pertanyaan penelitian.

Untuk memastikan tingkat kepercayaan penelitian peneliti menggunakan credibility dan confirmability (Lincoln dan Guba, 1985: 301321. Prinsip credibility dipenuhi peneliti dengan penggunaan 3 teknik pengumpulan data sekaligus dan member checking. Member checking dilakukan dengan memberikan hasil transkrip wawancara, observasi, dan penafsiran data kepada narasumber yang bersangkutan untuk diperiksa apakah informasi yang digunakan peneliti sudah tepat atau perlu perbaikan. Untuk prinsip confirmability, peneliti memenuhinya dengan diskusi terutama dengan rekan sesama peneliti berkaitan dengan kedalaman, cakupan, dan kesesuaian tafsiran data.

\section{B. HASIL DAN PEMBAHASAN}

\section{Penghormatan Melalui Dialog yang Setara}

Kekhasan dari proses belajar di SD Salam adalah dilakukanya dialog personal antara fasilitator dengan siswa baik terjadi di dalam kelas maupun di luar kelas. Dari dialog yang terjadi peneliti mencoba melacak bagaimana penghormatan diterapkan. Sebagai misal, seusai pelaksanaan Pasar Senin Legi (pasar yang diadakan dan dilaakssiswaan oleh siswa-siswa SD Salam setiap Senin Legi) biasanya akan dilakukan evaluasi di kelas masing-masing. Kelas 6 juga melakukan evaluasi terhadap pelaksanaan Pasar Senin Legi. Terjadi diskusi yang menarik antara fasilitator dan siswa kelas 6 .

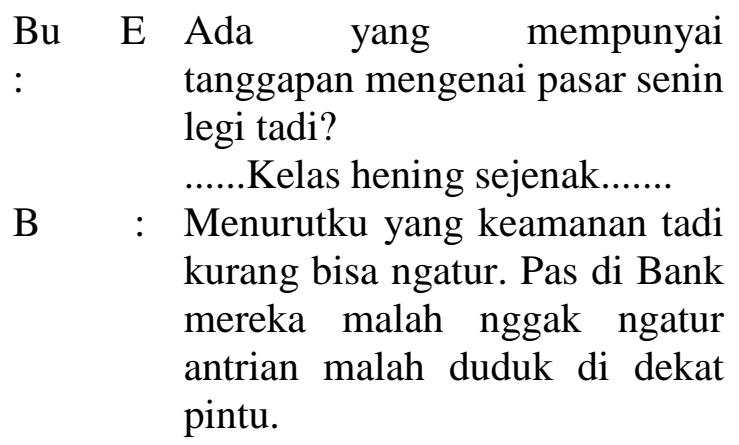


O Tadi juga pada malah beli-beli aku liat.

$\mathrm{Bu}$ E Kalo begitu menurut kalian sebaiknya bagaimana?

B Sebaiknya sebaiknya itu petugasnya dari kelas 5 dan 6 sama SMP gitu. Kita kan lebih 'strong'. Kalo yang kelas 34 itu keliatan kurang ee

Bu E : Oww gitu ya. Ide bagus itu. Jadi nanti memang pada kerja beneran nggak cuma pengen gajinya aja. $\mathrm{Na}$ trus nanti kalau yang siswa kelas 1 dan 2 pengin jadi keamanan bagaimana?

$\mathrm{O}$ : Nanti bisa disuru jadi pembeli dulu aja karena kan mereka belum bisa

B : Iya. Kalau enggak bisa tetap jadi keamanan tapi yang kelas 5,6, dan SMP tetep jadi yang ngatur-ngatur.

$\mathrm{BuE}$ : Ow gitu. Ide bagus itu.

(Observasi, 1/2/17)

Dialog yang terjadi antara $\mathrm{Bu} \mathrm{E}, \mathrm{O}$, dan $\mathrm{B}$ merupakan contoh cara berkomunikasi Fasilitator dengan siswa. Cara berkomunikasi mencerminkan bagaimana fasilitator menghormati dan menghargai siswa. Penghormatan fasilitator kepada siswa merupakan penghormatan kepada hak-hak dasar manusia. Terlihat dari dialog tersebut bahwa $\mathrm{Bu} \mathrm{E}$ sangat menghormati pendapat dan memberikan penghargaan atas ide yang telah siswa berikan dengan menyimak dan menanggapinya. $\mathrm{Bu} \mathrm{E}$ menunjukan simpatinya dengan tidak menjadi merasa lebih tahu atas persoalan yang sedang dibahas. Pola komunikasi yang demikian tidak akan terjadi apabila fasilitator mendominasi dialog atau hanya menggunakan kewenangannya untuk mengatur permasalahan di Pasar Senin Legi.

Pada kelas bawah, pola dialog yang mewujudkan penghormatan tidak jauh berbeda dengan kelas atas. Fasilitator tetap menitikberatkan penghormatan akan hak dasar siswa (berpendapat, berkreasi, dan memilih). Hanya saja fasilitator di kelas bawah cenderung menempatkan diri sebagai pihak yang sedikit tidak lebih tahu daripada si siswa. Hal tersebut terlihat dari pertanyaanpertanyaan balikan yang diberikan oleh fasilitator pada siswa.

Seperti yang dilakukan oleh $\mathrm{Bu} \mathrm{D}$ yang merupakan fasilitator kelas 2. Pada Awalnya siswa yang bernama $\mathrm{E}$ bermain kincir angin yang mereka buat pada pembelajaran sebelumnya. Entah apa penyebabnya, Bu D dan E terlibat obrolan mengenai pesawat.

Bu D: Apa sih bedanya helikopter dengan pesawat?

E : Kalau pesawat itu lintasanya lebih panjang. Lebih keren juga kan bisa banyak ngangkut orang

Bu D: Kalau helikopter?

E : Kalau helikopter pakai balingbaling. Mendaratnya bisa di atas gedung

Bu D: Kalau pesawat terbangnya gimana?

E : kayak gini (memperagakan dengan tangan yang diangkat ke atas dan digerakan ke kanan dan ke kiri).

Bu D: Kalau helikopter?

E : Kayak gini. Naik gitu (memperagakan dengan tangan yang diangkat ke atas seperti helikopter yang sedang lepas landas)

Bu D: Oooww. Kalau pesawat bisa kayak gitu enggak zi?

E : Nggak bisa yoo.

Bu D: Kenapa?

E : Yang bisa Cuma helikopter doang yang terbangnya kayak gini (mengangkat tanganya ke atas memperagakan helikopter).

Bu D: Kalau pesawat kayak capung, capung yang Ezzi critain itu bisa enggak?

E : Cuman capung itu pesawatnya latihan. Terbangnya juga kayak gini terus (memperagakan dengan tangannya). Bisa kayak gini ngeeeeeengg (memutar tangannya) kayak bulet-bulet tu lo bu.

Bu D: Kalau pesawat yang gede itu ada baling-balingnya enggak to?

E : Ada kalau pesawat yang panjang itu. Baling-balingnya di belakang yang jet itu

Bu D: Buat apa baling-balingnya itu?

E : Diam sejenak. Kalo baling-baling itu pesawat wings, hercules. Hercules kan baling-balingnya 4 
ada yang 6 (sambil menunjukan jarinya yang berjumlah 6 ).

Bu D: Masak itu enam? Coba di hitung.

E : tu, dua, ga, empat, lima, enam.

Bu D: ow iya enam. Kalau Hercules itu mendaratnya di Adi Sucipto juga?

E : Iya. Terus ada yang ke Madiun. Ya kan yang ada pesawat tempurnya tu loo. Yang buat perang-perang.

(Observasi,18/3/17)

Terlihat dari pertanyaan-pertanyaan yang diberikan $\mathrm{Bu} \mathrm{D}$ bahwa ia sengaja untuk memancing daya kritis E yang memang sangat tertarik dengan pesawat terbang. Ia memberikan kesempatan seluasluasnya kepada $\mathrm{E}$ untuk menuangkan pengetahuan dan pendapat-pendapatnya mengenai pesawat. Antusiasme $\mathrm{Bu}$ D juga nampak jelas sebagai pihak yang seolah belum mengetahui jawaban mengenai pertanyaan yang ia tanyakan. Dari nada bicara dan pilihan kata yang digunakan $\mathrm{Bu} \mathrm{D}$ juga berusaha menjadi seperti teman sebaya E.

Dapat diidentifikasi bahwa penghormatan yang dilakukan fasilitator kepada siswa merupakan penghormatan atas eksistensi siswa sebagai manusia dengan daya pikir dan potensi. Hal itu dilakukan dengan membangun dialog dengan prinsip kesetaraan intelektual dan penghargaan atas hak dasar siswa. Saat berdialog dengan siswa, fasilitator berusaha memodifikasi intelektualitasnya agar sepadan -tidak lebih pintar- dengan siswa. Selain itu, penghargaan atas eksistensi siswa terwujud pada diberinya kesempatan dan ruang untuk berpendapat, bertukar pikiran, dan bertanya mengenai apapun sebagai bentuk pemenuhan atas hak dasar siswa. Hal itu dapat diciptakan ketika fasilitator tidak menampilkan kode-kode atau bahasa-bahasa formalistik yang justru akan menjadi penghambat dalam menciptakan ruang yang nyaman bagi siswa untuk berpendapat.

Pola komunikasi antara fasilitator dan siswa yang dilingkupi suasana nyaman menimbulkan ungkapan penghormatan siswa kepada fasilitator. Ungkapan penghormatan menjadi menarik karena siswa menganggap fasilitator sebagai 'teman'. J siswa kelas 5 sangat dekat sekali dengan $\mathrm{Bu}$ W (fasilitator kelas 5). Setiap ada kejadian yang menggelitik atau menarik perhatian, J pasti akan menceritakan kejadian tersebut dengan berbisik kepada $\mathrm{Bu} \mathrm{W}$. Bu W biasanya mendengarkan sambil tersenyum-senyum. Begitu juga dengan siswa kelas 1 bernama $P$. Ia selalu menanyakan segala hal yang membuatnya tertarik kepada $\mathrm{Bu} \mathrm{Wi}$ (fasilitator kelas 1). Ia begitu leluasa tanpa beban menariknarik celana $\mathrm{Bu} \mathrm{Wi}$ sambil memanggil-manggil namanya berulang kali ketika $\mathrm{Bu}$ Wi lama merespon. Biasanya $\mathrm{Bu} \mathrm{Wi}$ akan menjawab sambil tersenyum dan setelah terjawab $\mathrm{P}$ terus menanyakan hal-hal lain. Dalam keseharian $\mathrm{P}$ memang siswa yang paling aktif bertanya, di sisi lain ia menyukai hal-hal baru di sekitarnya sehingga ia sangat aktif ketika berada di sekolah.

Kedekatan antara siswa dengan fasilitator juga terlihat di kelas 2. Pada saat istirahat, $\mathrm{Bu} \mathrm{N}$ (fasilitator kelas 2) biasa menyertakan diri berbaur ke dalam aktivitas siswa. Pada waktu itu, 5 siswa perempuan kelas 2 melakukan permainan cublak-cublak suweng. $\mathrm{Bu} \mathrm{N}$ bergabung dalam permainan tersebut. Siswa-siswa tidak lantas menjadi canggung, namun mereka tambah bersemangat ketika ada satu orang lagi mengikuti permainan tersebut. Tambah satu orang berarti akan meningkatkan tingkat kesulitan permainan tersebut. Ketika $\mathrm{Bu} \mathrm{N}$ harus kalah dan menjadi orang yang harus mencari suweng, tanpa rasa enggan ia menunduk ke bawah dan siswa-siswa mulai meletakan tanganya di punggung $\mathrm{Bu} N$ sambil menyanyi cublak-cublak suweng. Raut wajah siswa nampak tidak berubah -tetap ceriawalaupun yang 'jadi' kala itu adalah fasilitator mereka (Observasi, 18/3/17).

\section{Cublak-cublak Suweng}

Penghormatan yang terwujud di dalam pola interaksi antara siswa dengan fasilitator seharihari kental dengan nuansa persahabatan. Nuansa persahabatan bagi siswa menimbulkan suasana nyaman sehingga siswa dapat terbuka dengan fasilitator. Siswa terbuka dengan masalahnya, perasaanya, kesulitannya, dan kegelisahanya pada lingkungan sekitar. Penghormatan siswa SD Salam kepada fasilitatornya tidak ke terwujud dalam simbol-simbol artivisial yang biasa dilakukan di masyarakat kita seperti cium tangan ketika bertemu, menunduk ketika berjalan di depan orang tua, atau membatasi tutur kata agar memenuhi kriteria hormat pada orang yang lebih tua. Penghormatan siswa SD Salam justru terwujud pada perilaku yang mencerminkan bahwa siswa merasa memiliki dan mencintai fasilitatornya sebagai sahabat yang setia.

\section{Penghormatan Melalui Kegiatan Bersama di dalam Sekolah}

Penghormatan antara siswa dengan temannya dapat terwujud di dalam beberapa kegiatan yang 
dilakukan di SD Salam. Sejauh pengamatan peneliti berbagai kegiatan tersebut mencerminkan karakteristik penghormatan yang dilakukan siswa kepada temannya. Cerminan kegiatan yang telah menjadi kebiasaan tersebut diantaranya (1) mengantri, (2) mendengarkan teman yang sedang berbicara, (3) penyelesaian konflik antar teman, dan (4) aktivitas yang membaur.

\section{a) Mengantre}

Kegiatan yang bersifat komunal hampir setiap hari dilakukan di SD Salam. Kegiatan bersama tersebut biasanya dilakukan oleh seluruh warga sekolah atau paling tidak siswa-siswa dalam kelas. Kebiasan yang sering dilakukan siswa-siswa SD Salam ketika melakukan kegiatan bersama adalah mengantre. Misalnya, pada saat jam makan siang siswa-siswa selalu dibiasakan untuk mencuci piring masing-masing. Tempat cuci piring yang digunakan bermodel wastafel dengan satu kran air. Siswa-siswa biasanya mengantri berbaris ke belakang untuk dapat mencuci piring. Siswa-siswa terlihat tertib tanpa berebut posisi karena mereka menghargai teman yang datang duluan.

Selain pada saat akan mencuci piring, antri juga dilakukan sewaktu membeli makanan pada saat Pasar Senin Legi. Pada waktu itu peneliti mengamati salah satu siswa yang berjualan spageti yang merupakan buatan rumahan. Spaghetti dicampur dengan bumbu yang dikemas dalam pincukan kertas minyak. Ketika ada pembeli, barulah penjual mulai mempersiapkannya. Spageti yang dijualnya ternyata sangat diminati oleh siswa-siswa di SD Salam. Karena banyaknya peminat dan butuh waktu bagi penjual untuk mempersiapkan spagetinya, siswasiswa harus antri berbaris ke belakang sampai mendapatkan giliran untuk dilayani. Sekitar 5-6 siswa berbaris sambil menggenggam uang pecahan seribuan menanti gilirannya (Observasi, 1/2/17).

Kegiatan mengantri sudah menjadi kebiasaan yang dilakukan secara otomatis ketika siswa akan melakukan sesuatu terkait dengan acara bersama. Artinya, kegiatan mengantri sudah tertanam di dalam benak siswa-siswa sehingga masing-masing dari mereka memiliki kesadaran untuk menghormati orang lain dengan mengantre. Konflik yang berkaitan dengan kepentingan siswa untuk mendapatkan akses fasilitas publik ataupun akses untuk mendapatkan hal lainnya pun jarang terjadi. Antre merupakan kegiatan dalam rangka menjunjung kepentingan-kepentingan publik. Salah satu ciri keberhasilan pengelolaan kepentingan publik adalah apabila masing-masing pribadi menghargai hak-hak orang lain yang memang seharusnya didapat orang lain. Dengan mengantri, siswa dapat mengerti dan memahami bahwa orang yang datang terlebih dahulu berhak untuk mendapatkan akses lebih dahulu pula. Dengan begitu, siswa tidak akan menyerobot antrean dan menyebabkan terjadinya konflik kepentingan.

Dari proses mengantri terdapat nilai menghormati yang sangat mendasar dan berdampak pada nilai-nilai yang lainnya. Pertama siswa dapat belajar manajemen waktu. Ketika siswa ingin cepat mendapatkan akses, maka ia harus mengatur waktunya agar dapat datang lebih awal. Kedua, Siswa akan bersabar untuk menunggu gilirannya. Ketiga, ketika antrian cukup lama siswa-siswa belajar untuk mengisi waktu yang terbuang untuk mengantre. Kebiasaan di sebagian Eropa dan di Jepang orang akan mengisi waktu antri dengan bersosialisasi atau membaca buku. Keempat, siswa-siswa dibiasakan untuk menjunjung tinggi kepentingan publik dengan menumbuhkan persepsi publik bahwa menyerobot antrian adalah hal yang tidak pantas atau memalukan. Oleh karena itu, penghormatan akan kepentingan pubik membawa banyak dampak besar pada perkembangan afeksiafeksi yang lainnya.

\section{b) Mendengarkan teman yang sedang berbicara}

Penghormatan pada teman sebaya juga dilakukan siswa-siswa SD Salam saat ada teman yang berbicara di depan banyak orang. Momen berbicara di depan teman lain kebanyakan muncul di dalam dinamika pembelajaran di kelas. Siswa-siswa biasa mengemukakan usul atau ideide secara spontan. Ketika satu siswa berbicara mengungkapkan usulnya, siswa lain diam mendengarkan. Seperti pada saat diskusi mengenai tindak lanjut Pasar Senin Legi, B siswa kelas 6 memberikan tanggapan mengenai pelaksanaan pasar tersebut. Tanggapan B tidak cukup panjang, namun seluruh siswa mendengarkan B. Tidak terlihat siswa yang berbicara sendiri ataupun melakukan kegiatan yang membuat mereka tidak mendengarkan temannya. Tidak hanya ketika $\mathrm{B}$ berbicara, $\mathrm{O}$, Ed, dan siswa lain juga didengarkan oleh siswa (Observasi, 1/2/17)

Hal menarik mengenai menghargai teman yang diwujudkan dengan mendengarkan juga terjadi di kelas 5. Setelah Siswa melakukan riset 
di Pasar Ngasem, mereka diberikan kesempatan untuk bercerita mengenai apa saja yang telah mereka lakukan di Pasar Ngasem. Beberapa siswa telah bercerita dan sampailah giliran siswa yang bernama B. B adalah siswa yang berkebutuhan khusus dalam hal berbicara dan berkomunikasi. Ketika berbicara suaranya terdengar kecil dan pengucapan katanya terdengar kurang jelas. Kadang kala susunan kata dalam kalimat yang ia ucapkan kurang terangkai dengan sistematis sehingga sulit untuk dipahami. Meskipun demikian, pada saat ia bercerita mengenai kegiatan di Pasar Ngasem teman-teman dapat mendengarkan walaupun cerita yang disampaikan nampak kurang menarik. Terdapat beberapa teman seperti D dan A yang nampak tidak menikmati. Namun, mereka berusaha untuk tidak membuat gaduh atau membuat gerakgerik yang berpotensi mengalihkan perhatian teman lain sehingga tidak lagi memperhatikan Bagas (Observasi. 10/2/17).

Kebiasaan menghormati teman lain yang sedang berbicara juga mulai dilakukan pada siswa kelas bawah. Misalnya, setelah melakukan kegiatan pengamatan, siswa kelas 2 diberi tugas untuk membuat presentasi menggunakan kertas berukuran besar mengenai klasifikasi benda-benda yang telah mereka amati. Setelah itu, mereka diberi kesempatan untuk mempresentasikan di depan teman-teman satu kelas mengenai hasil kerja mereka. Kelompok yang presentasi selalu mendapatkan respek yang baik dari teman-teman kelompok lain. Mereka terlihat menyimak hasil kerja kelompok lain dengan begitu antusias walaupun ada beberapa anak yang memang kurang fokus terhadap presentasi temannya (Observasi. 17/3/17). Berikut foto yang menunjukan siswa-siswa yang memperhatikan presentasi dari temannya.

Penghormatan siswa-siswa kelas atas dan kelas bawah seperti tergambar dalam uraian di atas menunjukan sikap menghargai teman yang telah menjadi kebiasaan. Kebiasaan mendengarkan baik yang dilakukan siswa kelas bawah dan kelas atas memperlihatkan bahwa penghormatan dilakukan dengan menghargai keberadaan teman yang sedang mengungkapkan idenya melalui berbicara. Dapat dikatakan pula bahwa mendengarkan sebagai bagian dari menghormati dilakukan dengan pembudayaan berbasis kebiasaan bukan basis instruksional..

\section{c) Penyelesaian konflik antar teman}

Rasa hormat antar teman juga terlihat ketika siswa mengalami konflik dengan temannya. Konflik biasa terjadi karena kesalahpahaman atau salah satu pihak yang berkonflik memang berbuat salah. Dalam penyelesaian konflik, SD Salam memiliki metode tersendiri. Jika terjadi konflik ada beberapa tahapan yang harus dilakukan oleh fasilitator. Pertama, membiarkan siswa menyelesaikan konflik secara mandiri dengan teman yang berkonflik. Jika cara pertama tidak berhasil maka fasilitator wajib memfasilitasi pihak-pihak yang berkonflik. Fasilitator memfasilitasi dengan cara membiarkan semua pihak yang berkonflik untuk bicara bergantian. Kemudian fasilitator memandu siswa untuk mencari akar permasalahan. Setelah akar permasalahan dapat diidentifikasi, fasilitator akan memandu siswa untuk mengakui kesalahan masing-masing dan apa yang harus dilakukan agar hal serupa tidak lagi terjadi. Hal ini juga diungkapkan oleh Mas Yudhis dalam petikan wawancara berikut ini.

Peneliti : $\quad$ Mengenai konflik antar teman. Saya sering melihat antara siswa-siswa ini. Na, sebenarnya prinsip di Salam dalam menyelesaikan konflik itu sendiri bagaimana Pak?

Pak Y : hemm. Satu kalau kita ngomong konflik itu. Itu hal wajar yang di dunia ini. Naa, yang penting bagaimana kita menyikapi itu. Ee kita lihat si siswa apakah dia mampu menyelesaikan itu sendiri. Kalau kita menganggap dia mampu, cukup memperhatikan saja. Kedua, ketika kita melihat itu butuh bantuan ya kita harus masuk. Aa prinsipnya adalah mencari sebabnya apa kesalahan itu muncul kemudian diselesaikan bersama. Nah utamanya si siswa yang mencari penyelesaian kita membantu aja. Peranya tetap menjadi fasilitator.

ti : solusi akhirnya itu arahnya kemana Pak? Apa untuk perbaikan diri si siswa atau lebih ke win win solution? Atau bagaimana? 
nana bersikap atau bagaimana menyikapi suatu keadaan tertentu. Misalnya, ada siswa terpukul oleh temannya. Haa menangis. Responya bisa macem-macem. Bisa dia membalas memukul bisa dia berteriak-teriak. ...... Tapi ada siswa tertentu yang tidak membalas tapi lapor ke fasilitator misalnya. $\mathrm{Na}$ ini kan beda. Tetapi ada hal yang sama yaitu mencari tahu sebabnya apa. Kalau udah ketemu sebabnya. Ditanyakan sebaiknya sikapmu bagaimana? Perlu marah enggak? Perlu membalas enggak? Ini kita ajak ngomong hal yang mendasar. Terus sekarang bagaimana. Itu yang dicari. Bisa bedabeda (Wawancara, 11/3/17).

Penyelesaian konflik akan diarahkan pada tindakan pencegahan agar konflik tidak terjadi kembali. Atau dapat dikatakan pula, siswa dapat bersikap dengan tepat ketika menghadapi konflik. Melalui mekanisme penyelesaian konflik tersebut peneliti mengidentifikasi bagaimana kecenderungan siswa dalam menghargai teman sebayanya yang berkonflik dengannya.

Contoh peristiwa yang menggambarkan bahwa siswa mampu menyelesaikan peristiwa secara mandiri terlihat ketika siswa kelas 5 yang bernama B berkonflik dengan siswa kelas 1 yang bernama A. Pada waktu itu, siswa kelas 5 sedang menyelesaikan essay individual. Mereka diperbolehkan untuk bekerja dimanapun. Kebanyakan siswa bekerja di luar kelas termasuk B. Setelah waktu untuk menulis essay habis, B hendak masuk ke kelas. Namun ia memainkan bola terlebih dahulu dengan $\mathrm{R}$ di Lapangan. Saat ia memegang bola, tiba-tiba A berlari sambil berusaha merebut bola dari tangan B. B terlihat melakukan gerak refleks hingga memukul A pada bagian bahu. A terlihat menahan rasa sakit dengan memegang bahunya yang kena pukul, sambil masuk ke kelas 1 .

Bagas terlihat akan kembali memainkan bolanya tanpa memperdulikan A yang kesakitan. $\mathrm{R}$ melihat peristiwa tersebut kemudian dengan spontan meminta B untuk meminta maaf kepada A. Ia mengatakan bahwa Bagas harus meminta maaf karena itu sudah seharusnya ia lakukan jika melakukan hal yang salah. B kemudian menuju ke kelas 1 untuk mencari A. Pada awalnya A tidak mau menemui $\mathrm{B}$, entah apa alasannya peneliti tidak begitu mengetahui. Namun, Akhirnya A mau menemui B berkat bantuan Bu Wi (Fasilitator kelas 1) yang membantu memanggilkan. Ketika A sudah dihadapan B, B mengulurkan tangannya sambil mengucapkan kata maaf karena telah memukul A dengan pengucapan kata yang terbata-bata. A pun menyalami tanpa berucap apapun. Melihat kejadian tersebut, $\mathrm{Bu} \mathrm{Wi}$ bertanya "A bilang bagaimana?". Setelah mendengar itu, A mengucap bahwa ia juga minta maaf karena ingin merebut bola dan juga mengucapkan kata-kata ejekan kepada bagas dengan bantuan $\mathrm{Bu}$ Wi. Akhirnya Bagas dan A saling bermaafan (Observasi, 1. 18/2/17).

Selain contoh konflik tersebut, terdapat juga konflik yang tidak mampu diselesaikan oleh siswa sendiri sehingga harus melibatkan fasilitator dalam penyelesaiannya. Misalnya konflik antara B, D dan B siswa kelas 5. Konflik tersebut terjadi pada saat kegiatan home visit di rumah R. Kegiatan siswa-siswa waktu itu adalah menonton film dan melihat-lihat koleksi lukisan karya pelukis Tino Sidin yang merupakan eyang buyut R. Saat sedang melihat koleksi barangbarang Tino Sidin yang diletakan di dalam kotak kaca, nampak tangan B yang bersandar pada kaca meninggalkan bekas tangan dan kaca menjadi terkesan kotor. D dan B yang melihat kejadian tersebut langsung mengingatkan $\mathrm{B}$ untuk menghapus bekas tangannya. B kemudian berusaha menghapus dengan sekuat tenaga, namun masih terdapat noda yang tersisa di kaca.

$\mathrm{B}$ dan D terus-menerus mendesak Bagas untuk menghapus noda tersebut, namun Bagas berpendapat bahwa kaca tersebut sudah bersih. Namun B dan D masih saja mendesak B untuk membersihkan noda yang masih tersisa. Merasa tidak nyaman dengan desakan kedua temanya, Bagas kemudian membalas dengan berkata "ngece, ngece" yang artinya mengejek. Debat pun terjadi antara $\mathrm{B}$ dengan $\mathrm{D}$ dan $\mathrm{B}$. Terlihat kesabaran B mulai habis dan seketika ia memukul D dan B sambil menangis. Mereka pun terlibat kejar-kejaran hingga D dan B masuk ke kamar mandi dan B menggedor-gedor pintu kamar mandi agar D dan B keluar dari kamar. 
Mendengar suara pintu dipukul, $\mathrm{Bu} \mathrm{Av}$ (Fasilitator kelas 5) menghampiri ketiga siswa tersebut dan melerai mereka. $\mathrm{Bu}$ Av memulai dengan mempersilahkan $\mathrm{B}$ dan $\mathrm{D}$ untuk bicara mengenai kronologi kejadian. Mereka berdua pun berbicara bergantian. B terlihat beberapa kali memotong cerita D dan B karena ia ingin cepatcepat menyanggah, namun $\mathrm{Bu} \mathrm{Av}$ selalu menekankan bahwa nanti ada waktunya sendiri B untuk berbicara. Setelah D dan B selesai berbicara, B mulai bercerita juga mengenai kronologi kejadian sambil tersedak-sedak karena menangis. Dari cerita tersebut, $\mathrm{Bu} \mathrm{Av}$ memberikan beberapa pertanyaan terutama kepada B. Pertanyaan yang ia berikan misalnya "mengapa kamu memukul?", "apakah dengan memukul masalahmu akan selesai?", "apakah perlu untuk memukul?", dan "seharusnya bagaimana jika mengalami peristiwa yang sama?". Dengan berusaha menjawab pertanyaan-pertanyaan tersebut, B mulai menyadari kesalahannya dan ia juga telah mengetahui sikap apa yang harus diambil ketika berada di dalam situasi yang sama. Mereka bertiga pun saling meminta maaf dengan bersalaman (Observasi, 1. 2/3/17).

Melalui orientasi penyelesaian konflik tersebut, terlihat bagaimana siswa dilatih untuk menghargai dan menghormati temannya. Konflik dijadikan media pembelajaran agar siswa mampu menyadari kesalahan yang telah diperbuat agar dihari depan ia dapat lebih menghargai teman. Proses untuk menyadari kesalahan dilakukan dengan mengusut penyebab konflik hingga ke akarnya. Pengusutan konflik juga dilakukan oleh siswa sendiri, fasilitator hanya membimbing dengan menstimulasi dengan pertanyaan-pertanyaan. Dengan demikian, siswa mampu meminta maaf dan memberi maaf dengan kesadaran akan kesalahannya dan kesalahan temannya. Muaranya berujung pada kemampuan pengendalian diri agar jika terjadi masalah yang sama, siswa mampu mengedepankan proses dialog untuk menyelesaikan masalah.

Penghargaan terhadap teman juga tercermin bagaimana siswa memperlakukan temannya yang tengah berkonflik atau sedang menjalankan konsekuensi atas kesalahan yang telah diperbuat. Konsekuensi biasanya diwujudkan dengan sebuah kegiatan positif yang dapat dipilih oleh siswa sendiri. Biasanya siswa memilih untuk merapikan perpustakaan, membersihkan lahan yang ditanami, membantu Mbak Tu (Juru Masak di Salam), mengerjakan soal yang dibuat oleh teman sekelas, atau membaca buku yang telah ditentukan oleh fasilitator. Seperti terjadi kepada D, B, dan R siswa kelas 5. Ketiganya sama-sama terlambat ketika berangkat ke sekolah. Maka sesuai kesepakatan, mereka harus berkegiatan sendiri sampai waktu snack tiba. D memilih untuk membersihkan kebun yang ditanami oleh siswa kelas 5, Bagas memilih untuk membereskan perpustakaan, sementara $\mathrm{R}$ membantu Mbak $\mathrm{Tu}$ di Dapur. Pada saat yang bersamaan pula siswasiswa kelas 5 yang lain juga mengerjakan tugas di luar kelas sehingga dapat melihat atau berinteraksi langsung dengan siswa-siswa yang sedang menjalankan konsekuensi. Siswa-siswa yang tidak menjalankan konsekuensi terlihat bersikap biasa pada mereka yang menjalankan konsekuensi. Tidak terlihat kecenderungan tindakan negatif yang merendahkan, mengejek siswa yang sedang menjalankan konsekuensi (Observasi, 15/2/17). Mengenai hal ini, Bu Why (pemilik SD Salam) bercerita bahwa siswa-siswa di Salam memang selalu diajarkan untuk menghargai hingga memaklumi kesalahan temannya.

"Kalau yang nilai-nilai itu memang kita bangun dari awal ya bagaimana menghargai teman, bagaimana menjaga diri sendiri, menjaga teman, menjaga lingkungan itu kan kita tanamkan betul gitu ya. Jadi disini gak ada siswa yang mengejek-ejek kayak gitu. $\mathrm{Na}$ ini biasanya memang gitu virusnya kalau ada kemasukan yang ini (siswa pindahan dari sekolah lain). Pernah juga dulu itu ada yang nyuri ambil uang ... sampai ada sepeda ilang. Seumur-umur ya baru sekali itu. Sepedanya hilang dan siswanya juga menghilang. Tasnya ditinggal siswanya pergi. Sudah agak besar sih. Sudah kelas 6 . Na ini akhirnya siswa itu (siswa yang kehilangan sepeda) bisa punya keikhlasan. 'nggak papa kok kata bunda mungkin dia lebih membutuhkan dari saya"" (Wawancara.18/3/17)

Seperti apa yang dikatakan oleh Bu Why, siswa-siswa di SD Salam tidak hanya diajarkan untuk menghargai, mereka juga belajar untuk memaklumi kesalahan teman yang mustahil untuk dicari penyelesaiannya. Dengan konsep konsekuensi dan pemakluman yang demikian, konsekuensi tidak nampak sebagai hukuman. Konsekuensi nampak sebagai kegiatan yang berbeda dari teman kebanyakan namun dapat dijalankan siswa tanpa ada rasa berat hati atau rasa malu. Hal tersebut juga membentuk 
karakteristik penghormatan atau proses menghargai siswa yang tengah menjalankan konsekuensi. Siswa lain yang tidak menjalankan konsekuensi, tidak pernah memberi label pada siswa yang tengah menjalankan konsekuensi. Konsekuensi dipandang sebagai hal yang biasa karena siswa tidak menjalankan kesepakatan bersama. Siswa-siswa biasa menyebut konsekuensi dengan 'berkegiatan sendiri'. Dengan demikian, labeling seperti siswa bodoh, malas, atau julukan-julukan yang merepresentasikan hal negatif tidak pernah dikenakan pada siswa yang tengah menjalankan konsekuensi.

Sikap tidak menghormati kadang kala dipicu oleh labeling-labeling negatif terhadap seseorang atau sekelompok masyarakat. Labeling negatif ini menjerumuskan pada segregasi sosial yang secara lunak membimbing pada sikap tidak menghormati. Misalnya tidak menghormati difabel karena kekurangan fisik yang dimiliki. Penghormatan di SD Salam juga bertumpu pada kultur positif mengenai pandangan terhadap konsekuensi/hukuman. Anak yang menerima konsekuensi tidak di cap "trouble maker". Hal tersebut terjadi karena Fasilitator tidak mempromosikan hal-hal yang berkaitan dengan labeling tersebut. Maka, Fasilitator memiliki peranan penting untuk menciptakan kultur positif yang mempromosikan sikap saling menghormati.

\section{d) Siswa-siswa yang membaur}

Kegiatan yang mengharuskan siswa-siswa untuk membaur dari kelas 1 hingga kelas 6 sering dilakukan. Setiap pagi siswa-siswa kelas 1 hingga 6 berdoa pagi dan melakukan permainan bersama di halaman sekolah, atau kegiatan Pasar Ekspresi dan Pasar Senin Legi yang mengharuskan siswa untuk berinteraksi satu sama lain. Pada saat permainan pagi, fasilitator biasanya menyajikan permainan yang berbasis kelompok dan mengharuskan kerjasama sehingga siswa-siswa memiliki ruang untuk saling bersosialisasi. Kesempatan untuk bersosialisasi juga didapatkan siswa ketika kegiatan Pasar Senin Legi. Siswa-siswa yang berjualan, pembeli atau petugas pasar biasanya terdiri dari berbagai kelas. Pada saat melakukan transaksi di pasar, mau tidak mau siswa-siswa harus bersosialisasi dengan siswa yang berbeda kelas. Selain itu banyak kegiatan pembelajaran yang dilakukan secara bersama oleh siswa-siswa dari kelas 1 hingga kelas 6 seperti pelatihan SAR, kegiatan Kepanduan, dan berbagai kegiatan ekstrakurikuler. Oleh sebab itu, siswa-siswa SD
Salam begitu hafal nama-nama temannya dari kelas 1 hingga kelas 6.

Ketika berkegiatan bersama, tidak lantas siswa berkumpul membentuk kelompokkelompok tersendiri bersama teman akrabnya. Siswa-siswa terlihat membaur dengan teman yang berbeda kelas. Mereka tidak terlihat canggung apabila berinteraksi atau minimal berdekatan dengan teman yang berbeda usia atau berbeda kelas. Siswa kelas 6 mengajak berbincang 2 siswa kelas 1 di depan pintu kelas 1 . Berbaurnya siswa-siswa tanpa rasa canggung merupakan hasil dari penciptaan iklim persekolahan yang tidak memberikan ruang bagi siswa-siswa untuk membuat kelompok-kelompok tersendiri. SD Salam selalu mengusahakan berbagai kegiatan komunal yang mengharuskan siswa untuk berbaur dalam suasana kekeluargaan.

Proses belajar di SD Salam juga mendukung siswa untuk dapat berinteraksi dengan seluruh warga sekolah. Seperti dilakukan kelas 5. Pada waktu itu, siswa kelas 5 kekurangan petugas untuk membaca Kesepakatan Sanggar Siswa Alam untuk upacara hari senin. Bu Av (Fasilitator kelas 5) mengusulkan kepada siswasiswa untuk meminta bantuan kepada siswa SMP. Kemudian $\mathrm{N}$ beserta A menemui siswa SMP yang sedang belajar di kelas. $\mathrm{N}$ dan A meminta kesediaan satu teman SMP untuk menjadi petugas pembaca kesepakatan Sanggar Siswa Alam. $\mathrm{N}$ dan A berbicara di depan kelas SMP agar ada siswa SMP yang bersedia untuk membantu kelas 5 dalam bertugas upacara hari senin. Akhirnya T salah satu siswa SMP bersedia untuk membantu siswa kelas 5 (Observasi, 10/3/17).

Menurut pandangan peneliti, terciptanya keberanian siswa SD yang mampu bernegosiasi dengan siswa SMP karena didorong oleh beberapa faktor. Pertama, keakraban yang terbangun di 'luar kelas' tercipta tanpa memperhatikan batas usia, gender, tingkat perkembangan, dan tingkatan kelas. Kedua, melalui dinamika sehari-hari, SD Salam mampu membiaskan berbagai latar belakang siswa yang berbeda baik dari segi sosial budaya dan tingkat ekonomi menjadi satu kultur kesetaraan di sekolah. Ketiga, tidak ada konsepsi-konsepsi yang dibentuk atau kecenderungan interaksi yang menyebabkan terciptanya kesenjangan sosial yang tinggi di kalangan siswa bahkan juga fasilitator-fasilitator di SD Salam. Faktor-faktor 
tersebut juga mendorong adanya kecenderungan penghormatan yang tidak memandang status sosial atau status kelas dari masing-masing siswa SD Salam. Penghormatan dilakukan karena telah terciptanya kesadaran dari masing-masing siswa yang memandang siswa lain setara dengan dirinya.

\section{SIMPULAN}

Berdasarkan hasil analisis dan pembahasan, dapat ditarik benang merah bahwa terdapat bentukbentuk penghormatan yang membudaya di SD Salam. Bentuk-bentuk tersebut diantaranya (1) penghormatan terwujud melalui dialog yang setara antara siswa dengan fasilitator atau sebaliknya, (2) penghormatan terwujud melalui kegiatan bersama diantaranya mengantre, mendengarkan teman yang berbicara, menyelesaikan konflik antar teman, dan siswa yang saling membaur. Dialog yang setara memungkinkan tumbuhnya perasaan dihargai oleh guru sehingga siswa memiliki model/contoh untuk menghargai orang lain. Selain itu, kegiatan bersama yang mempromosikan sikap menghormati juga menjadi faktor pendukung lain. Proses pembudayaan tersebut dapat dilakukan dengan kebiasaan sehari-hari menjadi penekanan tersendiri bagi fasilitator dan pengelola SD Salam. Pembiasaan merupakan kunci dari model penghormatan yang terjadi di SD Salam.

Penelitian ini memberikan sumbangan berupa implikasi bahwa pembentukan karakter penghormatan tidak melulu melalui cara-cara yang sangat terstruktur seperti pemberlakuan aturan yang ketat untuk menghormati atau penggunaan hukuman sebagai sanksi. Pembentukan sikap hormatmenghormati juga dapat dibentuk melalui penghargaan martabat manusia yang terwujud melalui penghargaan pada pendapat, usul, cerita yang dikemukakan oleh siswa. Selain itu kegiatan dalam lingkup sekolah juga dapat disusun dengan sistem yang mengutamakan keadilan agar siswa dapat menghargai hak-hak siswa lain. Penghormatan yang menjunjung tinggi kesetaraan posisi dianjurkan untuk diterapkan pada lingkup yang lebih luas pada sekolah-sekolah umum.

\section{DAFTAR PUSTAKA}

Aloni, N. (2007). Enhancing humanity: The Philosophical foundation on humanistic education. Netherlands: Springer.

Bogdan, R. C \& Biklen, S. K. (2003). Qualitative research for education: An introduction to theory and methods. United State of America: Pearson Education Group, Inc.

Creswell, J. W. (2012). Research design: pendekatan kualitatif, kuantitatif, dan mixed. Yogyakarta: Pustaka Pelajar.

Elisa, E.I. (2011). Pentingnya Sikap Respek bari Pendidikan dalam Pembelajaran. Majalah Ilmiah Pembelajaran. Vol.7. 1-15

Fraenkel, J.R \& Wallen, N.I. (2006). How to design and evaluate research in education (ed. 6). USA: McGraw Hill.

Miles, M. B. \& Huberman, A. M. (1992). Analisis data kualitatif: Buku sumber tentang metode baru (terjemahan). Jakarta: Penerbit Universitas Indonesia Press.

Mu'in, F. (2011). Pendidikan karakter konstruksi teoritik dan praktik: Urgensi pendidikan progresif dan revitalisasi peran guru dan orang tua. Yogyakarta: Ar-Russ Media.

Nemiroff, G.H. (1992). Reconstructing education: Toward a pedagogy of critical humanism. New York, Wesport, London: Bergin \& Garvey.

Patterson (1985). Respect (Unconditional Positive Regard). The Therapeutic Relationship. Monterey,CA: Brooks/Cole.

Raharjo, T. (2015). Sekolah Biasa Saja. Yogyakarta: Progress.

Schillebeeckx, E. (1993). Church: Human story of God. New York: Crossroad. 